\title{
Kissinger, the Architect of Sinai-2 Agreement between Israel and Egypt, September 1975
}

\author{
By Moshe Gat
}

American Secretary of State Henry Kissinger, who controlled the American foreign policy, thought that it was possible to reach a comprehensive settlement to the ArabIsraeli conflict, but only in stages. This policy is known as a policy of step by step. The first step was the Agreements of Disengagement, which were essentially a military disengagement, between Egypt and Israel in January 1974 and between Israel and Syria in May of that Year. Kissinger focused on Egypt, the largest Arab Country. He sought an agreement which he assumed would continue to maintain the expansion of US influence in Egypt and in moderate Arab Countries, and would keep the Soviets out from the political process. He believed that in order to reach a settlement, which was of utmost importance to American interests, the US must put hard pressure, and forced the Israelis accept the proposed settlement, known as Sinai 2 agreement.

\section{Introduction}

Egypt had come to realize, even before the October 1973 War, that the United States alone could promote the peace process and lead to an Israeli withdrawal from the territories it occupying during the June 1967 War; for although the Soviets were able to supply them with the desirable types and amounts of weapons, they had no impact on Israeli policy.

By turning to the United States, the Egyptians had in fact opened the door to American influence in the Arab world, and particularly in Egypt. The ever diligent Secretary of State Henry Kissinger, who had been governing US foreign policy during President Nixon's administration and even more so during President Ford's, had relentlessly promoted a ceasefire in October $1973^{2}$. He later succeeded to bring about the signing of two Agreements of Disengagement between Israel and Egypt in January 1974, and Israel and Syria in May of that year. ${ }^{3}$ After the Agreements of disengagement the US Secretary

\footnotetext{
${ }^{*}$ Professor, Bar-Ilan University, Israel.

1. United States National Archives, College Park, MD (USNA), RG59/2062, Tel Aviv to SD, 15 April 1970; Y. Meital, Egypt's Struggle for Peace: Continuity and Change, 1967-1977 (Gainsville: University of Florida, 1997), 69; M. Heikal, Road to Ramadan (London: Collins, 1975), 91-92.

2. H. Kissinger, Mashber: Nihul Mediniut Hahutz Bemilhemet Yom Hakipurim Ubayetzi'a Meveyetnam [Crisis: The Anatomy of Two Major Foreign Policy Crises] (Jerusalem: Shalem, 2004), 257-60.

3. Foreign Relations of the United States (FRUS), 1969-1976: Arab-Israeli Dispute, 19741976, vol. 26, Memorandum of Conversation, Allon-Kissinger, 30 July 1974, and Kissinger to Ford, 19 August 1974; A. Shlaim, Kir ha-Barzel: Yisra'el ve-ha-Olam ha-Aravi [The Iron Wall: Israel and the Arab World] (Tel Aviv: Sifriat Aliyat Gag, 2005), 314; Y. Meital, Egypt's Struggle for Peace: Continuity and Change, 1967-1977 (Gainsville: University of Florida,
} 
of States strove in moving the political process in order to reach another agreement, especially between Israel and Egypt.

The purpose of this article is to analyze the strategy and the actions taken by the US Secretary of State in order to reach an agreement, which primarily served the interests of the US.

\section{US Policy}

From Kissinger's viewpoint, continued US mediation was essential, as it preserves political momentum while rendering the US a central axis in the region. It was obvious to the countries involved that any additional steps taken would be under the direction of the US Secretary of State. Any agreement between Israel and Egypt, or any other Arab country, would require the former to withdraw from the occupied territories. Kissinger focused his diplomatic efforts on Israel and Egypt.

Kissinger saw the United States gaining clout in the Middle East while pushing the Soviet Union out of the region. He believed that promoting the peace process between Israel and its Arab neighbors was an American duty, ${ }^{4}$ and that, in the absence of his country's involvement, the entire region would be on the slippery slope towards a war with devastating outcomes. He viewed the Middle East as the most dangerous place on earth. The seeds of war had been sown and an inter-power conflict was never off the table. War would have been detrimental to the US economy, as well as to Europe's and Japan's. It would have led to an oil embargo, brought the Soviets back to a leading influential position, and pushed Egypt to side with the extreme Arab states. Hence, an agreement between Egypt and Israel, he told the President, would put the U.S.A. ahead of the Soviets in the Middle East for some time to come. Agreement was very crucial to American interests than any time in history. ${ }^{5}$

Kissinger saw that the conflict was complex and elaborate, and knew that attempting to resolve it and reach a comprehensive agreement would be futile, and only lead to renewed stalemate followed by another war. His only option

1997), 144-45; L. Stein, Israel since the Six-Day War: Tears of Joy, Tears of Sorrow (Malden, MA: Policy Press, 2014), 143-44.

4. The National Archive, Kew, London (TNA), Foreign and Commonwealth Office (FCO),93/500, Washington to FCO, 10 October, 1974; FRUS, vol. 26, Memorandum of Conversation, 12 August, 1975; A. D. Crain, Ford Presidency: A History (Jefferson, North Carolina and London: McFarland and Co. Inc. Publisher, 2006), 132; L. Fischer, "Turning Point on the Road to Peace: The Government of Yitzhak Rabin and the Interim Agreement with Egypt (Sinai 2)," Israel Studies 19, no. 3 (Fall, 2014): 57-58; G. Rafael, Be-Sod Le'umim: Shloshim Shnot Mediniyut Huts, Mabat mi-Bifnim [Destination Peace: Three Decades of Israeli Foreign Policy] (Jerusalem: Idanim, 1981), 182; W. B. Quandt, "Kissinger and the Arab-Israeli Disengagement Negotiations," Journal of International Affairs 29, no. 1 (Spring 1975): 40.

5. FRUS, vol. 26, Kissinger to Scowcroft, no date (Document no. 110); A.D. Miller, Arets ha-Mubtahat Me'od: Ha-Mirdaf ha-Matmid shel America Aherei Shalom ba-Mizrah haTickhon [The Much Promised Land: America's elusive Search for an Arab-Israeli Peace] (Tel Aviv: Yediot Ahronot, 2008), 148. 
was to adopt a step-by-step policy of partial agreements that will eventually lead to a comprehensive one. His biggest problem, however, was Israel. He viewed the Egyptian President, Sadat, as a great statesman one could "do business with" in light of Sadat's attempts, even before the 1973 War, to reach partial agreement with Israel, and his willingness to sign a peace agreement with it provided that all territories occupied by Israel be returned. ${ }^{6}$ It was the Israeli political structure that Kissinger believed formed an obstacle on the road to peace. The Israeli government and its administrators were engaged in a power struggle that prevented both mobility and tough decision-making. Prime Minister Rabin was weak and new in office, and thus unable to move forward. ${ }^{7}$

Thus in the pursuit of another accord between Egypt and Israel, the United States had resorted to exerting pressure on the Israeli administration by halting weapon shipments, denying financial aid and holding no discussions on future weapon transactions. In Kissinger's opinion, a country receiving aid to such an unprecedented extent cannot possibly be in the position to dictate US policy, and the United States cannot afford that its policy be subjected to Israel's domestic policies. Stagnation invites serious dangers. ${ }^{8}$

President Ford agreed. Weapons shipment must be stopped until Israel's policy become clear regarding the agreement with Egypt. That is, he said to Kissinger, "a hole card we control". To the Israeli Prime Minister he wrote, that the U.S. would do its best to ensure Israel's security, supply sophisticated weapons and provide financial aid, but that would be linked to the political progress. $^{9}$

\section{The First Round}

Both Egypt and Israel were willing to accept the step-by-step policy. Kissinger acted as mediator in the negotiations that began in the final quarter of 1974 and continued until September 1975. Israeli Prime Minister Rabin sought a political agreement, rather than a military one, that would constitute a meaningful step towards peace between Israel and Egypt. A peace accord with the largest Arab state meant removing it from the war cycle and rendering another comprehensive war unlikely. The extent of the withdrawal from Sinai Peninsula would depend on the political price Egypt would be willing to pay, quid pro quo. A meaningful withdrawal from Sinai would require Egypt to

6. FRUS, vol. 26, Memorandum of Conversation, 9 February 1975; USNA, RG59/5403/5, Kissinger to Ford, 14 August, 1974; M. Heikal, Secret Channels: The Inside Story of Arab-Israeli Peace Negotiations, (London: Harper and Collins, 1996), 240.

7. USNA, RG59/5403/21, Memorandum of conversation, 13 August, 1974; FRUS, vol. 26, Kissinger to Scowcroft, no date (Document no. 110), and Memorandum of Conversation, 19 February, 1975.

8. USNA, RG59/5403, Scowcroft to Ford, 3 November, 1974.

9. FRUS, vol.26, Memorandum of conversation, 12 August, 1974; G. R. Ford, A Time to Heal: An Autobiography of Gerald R. Ford (New York: Harper and Row, 1979), 245; Y. Goldstein, Rabin: Biografya [Rabin: A Biography] (Tel Aviv: Schoken, 2006), 268-69. 
publicly declare non-belligerence. Israel's slogan was, "a piece of land for a piece of peace" 10

Egyptian President sought a meaningful withdrawal from Sinai. In exchange for control over Mitla and Gidi, two strategic passes in Sinai, as well as the Abu Rudeis oil fields, he was willing to commit himself to a series of practical steps that would be equivalent of non-belligerency. However, a public non-belligerence declaration may have caused rage in the Arab world, and particularly in Egypt. They would view it as betrayal since the Israelis were still occupying most of the Sinai Peninsula. To declare non-warfare would therefore have meant his own destruction. ${ }^{11}$

Kissinger thought the Israeli demand that Egypt declare non-belligerence was nothing short of stubborn; their inability to see the full picture left them with a narrow perspective. It is no trivial matter for an Arab state for the first time to say that it would not regress to the use or threat of force, and that all conflicts henceforth shall be resolved peacefully. ${ }^{12}$ The Israeli government must alter its strategy and consider a broader one that serves both its own interests and those of the United States. A peace accord would be a huge step in the prevention of another war; it would increase American clout in the region while pushing the Soviets out. The terms were of lesser importance. The true significance lay in a peace process that is moving forward. Therefore the Israeli demand for quid pro quo is impossible - Egypt would be getting both passes and oil fields, whereas Israel would receive promises and words. ${ }^{13}$

10. TNA, FCO93/529, Minute by the FCO, 8 July, 1974; USNA, RG59/5403/10, Record of Conversation, Rabin-Kissinger, 10 September, 1974; L. Fischer, "Turning Point", 62; Y. Rabin, Pinkas Sherut [Service Notebook] Vols.1-2 (Tel Aviv: Sifriyat Ma'ariv, 1979), 447; D. Goldstein, "Special interview with Rabin," Ma'ariv, September 25, 1974; Crain, Ford Presidency, 132; S. L. Spiegel, The Other Arab-Israeli Conflict: Making America's Middle East Policy from Truman to Reagan (Chicago: University of Chicago Press), 289.

11. USNA, RG59/5403/5, Memorandum of Conversation, Sadat-Kissinger, 10 October, 1974, and RG59/5403/2, Rabin-Kissinger, 12 October, 1974; Y. Rabin, Service Notebook, vol. 2, 445; Crain, The Ford Presidency, 133; S, Touval, The Peace Brokers: Mediators in the Arab-Israeli Conflict, 1948-1979 (Princeton: Princeton University Press, 1982), 262; K. W. Stein, Heroic Diplomacy: Sadat, Kissinger, Carter, Begin and the quest for Arab-Israeli Peace (New York: Routledge, 1999), 211.

12. Gerald R. Ford Library and Museum, MI, Kissinger Reports, Kissinger to Ford, 22 March, 1975; In this connection see, M. Golan, Hasihot Hasodiot shel Henry Kissinger [The Secret Conversations of Henry Kissinger] (Jerusalem: Schoken, 1976), 167; FRUS, vol. 26, Memorandum of Conversation. 22 March, 1975.

13. FRUS, vol. 26, Memorandum of Conversation, 20 and 22 March, 1975; K. W. Stein, Heroic Diplomacy, 214-15; H. H. Saunders and A. Cacilia, Sinai II: The Politics of International Mediation, 1974-1975 (Washington D.C.: John Hopkins University, 1993), 54; A. Ben-Zvi, The United States and Israel: The Limits of the Special Relationship (New York: Columbia University Press, 1993), 95; Rabin. Service Notebook, vol. 2, 458; Gerald R.Ford Library and Museum, Memorandum of Conversation, 20 and 21 March, 1975. 


\section{Second Round-March 1975}

Feeling he has reached an impasse, Kissinger urged President Ford, who had only been in office for several months, to intervene. In fact, the Secretary of State dictated the desirable path of pressuring Israel to the newly appointed president. And Ford had indeed made it perfectly clear to the Israelis that the US would not allow stalemate in the peace process to expose all parties involved to the risk of war, oil embargo and potential conflict with the USSR. Financial aid and weapon shipments would be halted until Israel makes tough choices to promote the peace process. To Rabin he wrote on 21 March, "The failure achieve an agreement is bound to have far-reaching effects in the area and on our relations. I have directed an immediate reassessment of U.S. policy in the area, including our relations with Israel, with a view to assuring the overall interests of America in the Middle East and globally will be protected". ${ }^{14}$

Yet Israel remained true to its belief that Egypt must declare nonbelligerence if it wants Israel to withdraw from the passes and oil fields, or else Israel would only withdraw to a border that does not jeopardize its security. "The tragedy", Kissinger said to Ford, "is that Israel knows it must have an agreement and yet is paralyzed by its domestic policies." 15

Sadat was willing to meet the Israelis half way and assured them that in the accord for the transfer of the passes and oil fields to Egypt, the latter would undertake, inter alia, to: have the interim agreement form a step towards peace; seek to resolve all issues peacefully and refrain from use of force; keep the agreement in effect until it is replaced by another; and allow cargo ships headed for Israel to pass through the Suez Canal. Moreover, an agreement with Israel would not bind Egypt to any Arab states, should Syria, for example, engage in a war against Israel, Egypt would not join it. ${ }^{16}$

In light of Egypt's flexibility, Kissinger reiterated the importance of an agreement to Israel, stressing it would strengthen the moderate parts of the Arab world, prevent war, push the Soviets out and render irrelevant the reconvening of the Geneva Conference that Israel was so apprehensive about. He further stated that the failure to reach an agreement with Egypt would have catastrophic repercussions, outlining an apocalyptic forecast for the day that followed Israel's rejection of the offer made. Kissinger's bleak outlook did not startle the Israelis, who were familiar with his exaggeration and excessive sentimentality. They also did not fear another war, which they believed to be

14. Y. Rabin, Service Notebook, Vol. 2, 460.

15. TNA, FCO93/749, Kissinger Meeting with Callaghan, 23 March, 1975; FRUS, vol. 26, Scowcroft to Ford, 22 March, 1975.

16. TNA, FCO93/749, Washington to FCO, 29 April, 1975; FRUS, vol. 26, Scowcroft to Ford, 14 March, 1975; Y. Rabin, Service Notebook, 458; A. Shifris, Memshelet Rabin Harishona [The First Rabin Government] (Tsur Yigal: Porat, 2011), 36; K.W. Stein, Heroic Diplomacy, 214. 
unlikely, and for which they felt they were well-prepared in the event that it should indeed be waged. ${ }^{17}$

Kissinger therefore proceeded to tell President Ford that Israel was coldbloodedly playing with American national interests and that significant steps should be taken to force the Israeli government to accept the arrangement placed on the table. ${ }^{18}$ Against this backdrop a reassessment policy was adopted on March 1975, for which the US Secretary of State was aiming from the start in the event that Israel rejected the proposed agreement with Egypt. According to the reassessment policy, the United States would halt the provision of arms and aid to Israel, threaten to reconvene the Geneva Conference which was of great concern to Israel, and submit a comprehensive agreement plan. Kissinger strove to display the extent of US determination to protect its interests before the Israelis. ${ }^{19}$ However, the reassessment policy was not designed to place Israel's security in jeopardy. Actually there was nothing to reassess. Its aim was primarily psychological and formed part of Kissinger's campaign to impose the proposed agreement on the Israeli government, and kept cool with Arabs. ${ }^{20}$ Kissinger made every effort in continuing the political process in order to reach an agreement, which served American national interests. Hence Ford's decision to invite both Sadat and Rabin to meet him, separately, in order to find a way to break the deadlock.

\section{Toward an Agreement}

In June 1975 a meeting was held between President Ford and President Sadat in an attempt to solve the peace process standstill. Sadat asked for President's help in trying to convince those idiots in Israel to come to their sense. During the meeting Egyptian president expressed his willingness to become more flexible and place two monitoring stations - one Israeli and the other Egyptian - in the passes. He was also willing to reposition UN troops in Sinai each year and to keep the agreement in force until it is replaced by another. As far as Kissinger was concerned, Sadat had provided all the factors comprising non-belligerence in order to reassure the worried Israelis. ${ }^{21}$

But the latter stuck to their guns. In the meeting with ford on 11 June Rabin told the President that the Israeli government was interested in an

17. Y. Rabin, Service Notebook, vol. 2, 458; Ford Library, Memorandum of Conversation, 20 and 21 March, 1975.ford

18. FRUS, vol. 26, Memorandum of Conversation, 24 March, 1975; TNA, FCO93/748, FCO to Washington, 24 March, 1975; G. R. Ford, Time to Heal, 247; Miller, Promised Land, 155; E. Siilasvuo, In Search of Peace in the Middle East (London: Hurst and Co., 1992), 302.

19. A. Ben-Zvi, "Paradigm Lost? The Limits of the American-Israeli Relationship," Israel Affairs 4, no. 2 (Winter, 1997): 4-5; A.D. Miller, Ha-Arets ha-Mubtahat Me'od: Ha-Mirdaf haMatmid shel America Aherei Shalom ba-Mizrah ha-Tickhon [The Much Promised Land: America's elusive Search for an Arab-Israeli Peace] (Tel Aviv: Yediot Ahronot, 2008), 15657.

20. Ibid., 160. USNA, RG59/5403/24, Kissinger to Ford, 27 June 1975; FRUS, vol. 26, Memorandum of Conversation, 24 and 27 March, 1975.

21. USNA, RG59/5403/11, Meeting with Sadat, 1-2 June, 1975. 
interim agreement not just another military disengagement, but a step toward peace. $^{22}$ In the same day he said emphatically to Kissinger, "either an end to the state of belligerency or something of such length that by itself would create such a change". ${ }^{23}$ Rabin was concerned that once Egypt would regain the passes and oil fields, and having failed to declare non-belligerence, it would have no reason to continue with the peace process. He believed that the Egyptian President was working on salami tactics to weaken Israel. ${ }^{24}$

Kissinger refused to give up. He told President Ford that determination would ultimately break the Israelis. He found an agreement so crucial to American interests that he kept it as a central axis in the peace process. Kissinger therefore proceeded to exert tremendous pressure on Israel, and ultimately caused a crisis. He told Rabin: "You said you would protect your interests so we will protect ours... and we should go our own way and consult our own interests". ${ }^{25}$ President Ford underscored that "our judgement is that Israel's position is forcing the evolution of negotiations towards an outcome which runs counter to the interests of the United States and the world ${ }^{26}$."

The Israelis realized that more attention was paid to their relations with the United States than the agreement with Egypt. Crisis with the U.S.A. meant politically and strategically destructive to Israel, and in light of the exerted pressure consented to sign the agreement known as Sinai II in early September 1975 , in the format put forth by Kissinger. ${ }^{27}$ Needless to mention that Israelis were promised generous financial aid, diplomatic support, and a supply of oil and weapons. ${ }^{28}$

\section{Conclusion}

The US Secretary of State proved during a year of exhausting negotiations that he was able to overcome great difficulties, especially from the Israelis, and lead Israel and Egypt to sign an agreement. The step-by-step policy proved its worth in light of the depth and complexity of the conflict. Kissinger worked relentlessly to achieve the agreement since he believed that such an agreement between Israel and Egypt was a national American interest, which ensured the

22. USNA, RG5403/11, Memorandum of Conversation, 11 June, 1975.

23. Rabin, Service Notebook, vol.2, 477-78; USNA, RG59/5403/11, Memorandum of Conversation, 11 June, 1975.

24. USNA, RG59/5403/9, Memorandum of Conversation, 17 June, 1975.

25. USNA, RG59/5403/11, Memorandum of Conversation, 15 June, 1975.

26. FRUS, vol. 26, Memorandum of Conversation, 27 June, 1975.

27. USNA, RG59/5403/24, Memorandum of Conversation, 27 June, 1975; FRUS, 19691976; Arab-Israeli Dispute, vol. 26, Memorandum of Conversation, 1 July, 1975; E. Inbar, Rabin Vehabitahon Haleumi shel Yisrael [Rabin and Israel's National Security] (Tel Aviv: Misrad Habitahon, 2004), 69; G. Ya'acobi, Hesed ha-Zman: Pirkei Otobiyografya [Grace of Time: An Autobiography] (Tel Aviv: Sifriat Chemed, 2002), 133-34; A. Shifris, Rabin Government, 51.

28. G. R. Ford, A Time to Heal, 308-9; A. D. Miller, Promised Land, 160; Y. Rabin, Service Notebook, vol.2, 493; M. Riad, Struggle for Peace in the Middle East (London: Quartet Books, 1981), 294. 
alienation of the Soviet Union and the continuation of US influence in the region. The agreement, which set the stage for the United States to play a key role in the region, had also paved the way for the comprehensive peace accord signed by the parties in March 1979.

\section{Bibliography}

Ben-Zvi, A. "Paradigm Lost? The Limits of the American-Israeli Relationship." Israel Affairs 4, no. 2 (Winter, 1997):1-25.

Ben-Zvi, A. The United States and Israel: The Limits of the Special Relationship. New York: Columbia University Press, 1993.

Crain, A. D. The Ford Presidency: A History. Jefferson, North Carolina and London: McFarland and Co. Inc. Publisher, 2006.

Fischer, L. "Turning Point on the Road to Peace: The Government of Yitzhak Rabin and the Interim Agreement with Egypt (Sinai 2)." Israel Studies 19, no. 3 (Fall, 2014): 55-80.

Ford, G. R. A Time to Heal: An Autobiography of Gerald R. Ford. New York: Harper and Row, 1979.

Gerald R. Ford Library and Museum. http://1.usa.gov/1r2C7ZL.

Foreign Relations of the United States (FRUS). 1969-1976: Arab-Israeli Dispute, 1974-1976, vol. 26. Edited by A.M. Howard. Washington, United States: Government Printing Office, 2011.

Golan, M. Hasihot Hasodiot shel Henry Kissinger [The Secret Conversations of Henry Kissinger]. Jerusalem: Schoken, 1976.

Goldstein, Y. Rabin: Biografya [Rabin: A Biography]. Tel Aviv: Schoken, 2006.

Goldstein, D. "Special interview with Rabin." Ma'ariv, September 25, 1974.

Heikal M. Road to Ramadan. London: Collins, 1975.

Heikal, M. Secret Channels: The Inside Story of Arab-Israeli Peace Negotiations. London: Harper and Collins, 1996.

Inbar, E. Rabin Vehabitahon Haleumi shel Yisrael [Rabin and Israel's National Security]. Tel Aviv: Misrad Habitahon, 2004.

Kissinger, H. Mashber: Nihul Mediniut Hahutz Bemilhemet Yom Hakipurim Ubayetzi'a Meveyetnam [Crisis: The Anatomy of Two Major Foreign Policy Crises]. Jerusalem: Shalem, 2004.

Meital, Y. Egypt's Struggle for Peace: Continuity and Change, 1967-1977. Gainsville: University of Florida, 1997.

Miller, A. D. Ha-Arets ha-Mubtahat Me'od: Ha-Mirdaf ha-Matmid shel America Aherei Shalom ba-Mizrah ha-Tickhon [The Much Promised Land: America's elusive Search for an Arab-Israeli Peace]. Tel Aviv: Yediot Ahronot, 2008.

Quandt, W. B. "Kissinger and the Arab-Israeli Disengagement Negotiations". Journal of International Affairs 29, no. 1 (Spring 1975):33-48.

Rabin, Y. Pinkas Sherut [Service Notebook] Vols.1-2. Tel Aviv: Sifriyat Ma'ariv, 1979.

Rafael, G. Be-Sod Le'umim: Shloshim Shnot Mediniyut Huts, Mabat mi-Bifnim [Destination Peace: Three Decades of Israeli Foreign Policy]. Jerusalem: Idanim, 1981.

Riad, M. Struggle for Peace in the Middle East. London: Quartet Books, 1981.

Saunders, H. H. and A. Cacilia. Sinai II: The Politics of International Mediation, 1974-1975. Washington D.C.: John Hopkins University, 1993. 
Shifris, A. Memshelet Rabin Harishona [The First Rabin Government]. Tsur Yigal: Porat, 2011.

Shlaim, A. Kir ha-Barzel: Yisra'el ve-ha-Olam ha-Aravi [The Iron Wall: Israel and the Arab World]. Tel Aviv: Sifriat Aliyat Gag, 2005.

Siilasvuo, E. In Search of Peace in the Middle East. London: Hurst and Co., 1992.

Spiegel, S. L. The Other Arab-Israeli Conflict: Making America's Middle East Policy from Truman to Reagan. Chicago: University of Chicago Press, 1985.

Stein, K. W. Heroic Diplomacy: Sadat, Kissinger, Carter, Begin and the quest for Arab-Israeli Peace. New York: Routledge, 1999.

Stein, L. Israel since the Six-Day War: Tears of Joy, Tears of Sorrow. Malden, MA: Policy Press, 2014.

Touval, S. The Peace Brokers: Mediators in the Arab-Israeli Conflict, 1948-1979. Princeton: Princeton University Press, 1982.

The National Archive, Kew, London (TNA), Foreign and Commonwealth Office (FCO), 93/500, 529,749.

United States National Archives, College Park, MD (USNA). Record Group RG59/2062, 5403.

Ya'acobi, G. Hesed ha-Zman: Pirkei Otobiyografya [Grace of Time: An Autobiography]. Tel Aviv: Sifriat Chemed, 2002. 
